Provided for non-commercial research and education use. Not for reproduction, distribution or commercial use.

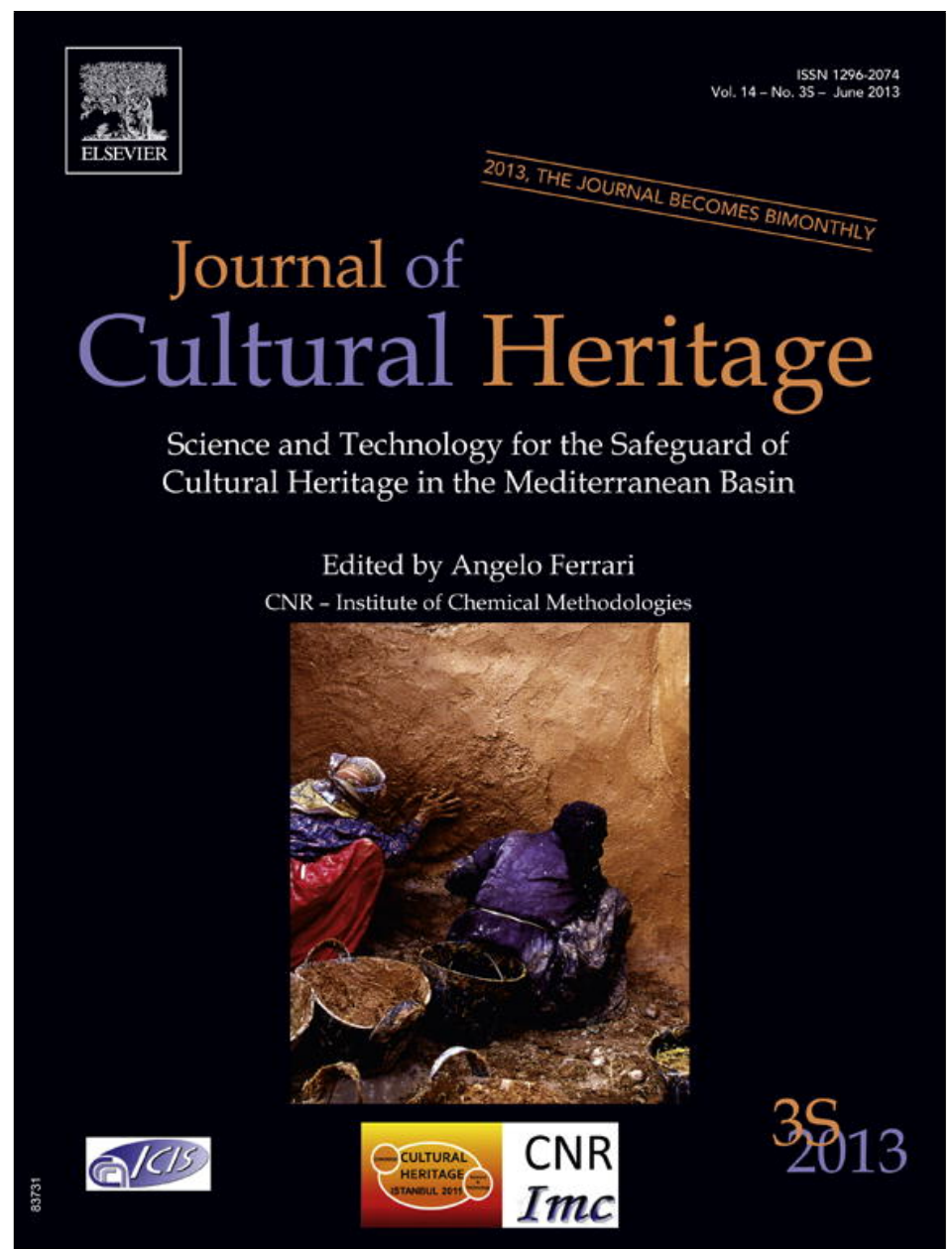

This article appeared in a journal published by Elsevier. The attached copy is furnished to the author for internal non-commercial research and education use, including for instruction at the authors institution and sharing with colleagues.

Other uses, including reproduction and distribution, or selling or licensing copies, or posting to personal, institutional or third party websites are prohibited.

In most cases authors are permitted to post their version of the article (e.g. in Word or Tex form) to their personal website or institutional repository. Authors requiring further information regarding Elsevier's archiving and manuscript policies are encouraged to visit: 


\title{
Exotic insect pests: The impact of the Red Palm Weevil on natural and cultural heritage in Palermo (Italy)
}

\author{
Barbara Manachini*, Noemi Billeci, Franco Palla \\ Dep. Environmental Biology and Biodiversity, University of Palermo, Via Archirafi 38, 90123 Palermo, Italy
}

\section{A R T I C L E I N F O}

\section{Article history:}

Received 26 October 2012

Accepted 5 November 2012

Available online 14 February 2013

\section{Keywords:}

Rhynchophorus ferrugineus

Phoenix canariensis

Chameropsis humilis

Protected areas

Biodiversity

\begin{abstract}
A B S T R A C T
The impact of invasive exotic pests is increasingly recognised as a global issue. A global strategy to address the exotic pest problem is beginning to evolve, albeit slowly. The International Plant Protection Convention (FAO) has begun the process of harmonizing standards for pest risk analysis to minimise the spread of exotic pests without adversely impacting global trade. However if the impacts of insect invasive species on human health and on agriculture have attracted worldwide attention, researchers and policymakers address directly the connection between invasive species and damage to natural and cultural heritages. The cost of these losses is generally neglected or underestimated. Various attempts have been made to treat the plants or the wood that affected by invasive species. But studies of the links between these pests and their effects on natural biodiversity and heritage, in botanical and historical gardens, are largely lacking in the literature. This paper examines categories of pest risk threatening the Mediterranean, with special emphasis on the author's homeland. We report the case of the invasive species Rhynchophorus ferrugineus (Red Palm Weevil, RPW) recently introduced into Europe. With an interdisciplinary approach, and by focusing on the situation in Sicily, we analyse how the RPW could be considered not only a pest impacting palm trees, but also natural and cultural assets and heritage.
\end{abstract}

(c) 2013 Elsevier Masson SAS. All rights reserved.

\section{Invasive pests and their direct and indirect impact}

One of the unintended consequences of the globalisation of trade has been the increase in the frequency and number of exotic (alien, introduced, foreign, non-native, or non-indigenous) species intercepted mainly at ports of entry [1-3]. This is largely due to the increase in the volume of trade and a broadening of trading partners, especially with the Pacific Rim and Asia. Non-indigenous species, or non-native, plants or animals adversely affect - economically, environmentally, and/or ecologically - the habitats and bioregions they invade [4]. Alien species use disruption by dominating a region, wilderness areas, particular habitats, and/or the wildland-urban interface land because of a lack of natural control. Exotic pests can enter a country through a number of pathways including logs, chips, unseasoned lumber, solid wood packaging material as propagative material, and also hitchhikers. Although most introduced organisms fail to become established, history has shown that the potential for damage is large if they do.

Economic costs from invasive species can be separated into direct costs of production loss in agriculture and forestry, and management costs for the containment of invasive species. Estimated

\footnotetext{
* Corresponding author. Tel.: +39 09123891827.

E-mail address: barbara.manachini@unipa.it (B. Manachini).
}

damage and control costs related to invasive species in the U.S. alone amount to more than $\$ 138$ billion annually [5]. In addition to these costs, economic losses can occur in the form of diminish recreational and tourism revenues. When economic costs of invasions are calculated as production loss and management costs, they are low because they do not consider environmental damage; if monetary values were assigned to the extinction of species, loss in biodiversity, and loss of ecosystem services, the calculated costs of impacts of invasive species would drastically increase. The impact of invasive pests on human health and on agriculture has attracted worldwide attention [6]. However, researchers and policymakers rarely address directly the connection between invasive species and loss in natural and cultural heritages. Invasive species have substantial, albeit not fully quantified, impacts on cultural services including aesthetic values, recreation, and tourism $[6,7]$, though studies of the links between these species and loss in natural biodiversity and heritage, in botanical and historical gardens as well as in natural landscapes, are largely lacking in the literature. In addition cultural legacy could be threatened. For instance, historic buildings are threatened by exotic wood-boring pests, as reported in the National Nonindigenous Species Workshop [8]; "The wooden buildings in New Orleans' French Quarter could "disappear" in twenty years due to the Formosan termite (Insecta: Isoptera); it also infests a third of New Orleans' (USA) historic live oaks". Another example of cultural loss is the decline in native 
plants of cultural significance to Native American tribes. Many of these culturally important native plants decline due to the spread of invasive plants such as spotted knapweed and sulphur cinquefoil (Potentilla recta) or invasive insects [3]. During the past century, exotic pests have destroyed the ecologic, cultural and economic value of many of the world's most versatile and important trees. Countries in Europe and around the globe have suffered the consequences from the introduction of pests into highly vulnerable tree populations: e.g. the pinewood nematode, the causal agent of pine wilt disease, was introduced into Japan, South Korea, Taiwan, China, and recently, Portugal and it destroyed thousands of hectares of forests; in New Zealand in the 1950s, Sirex noctilio (Insecta: Hymenoptera) destroyed an estimated $30 \%$ of 120,000 ha of pine (Pinus radiate) plantations within a land area of $20,000 \mathrm{~km}^{2}$, and in Australia in 1987 caused the death of 1.8 million trees worth about 5 million Australian dollars (AUD).

Other important pests which may have an impact on cultural heritage include Lyctus brunneus Stephens (Insecta: Coleoptera, Lyctidae). This pest originates in the tropics and was recorded for the first time in Venice in 1972; it is more aggressive and prolific (60-70 eggs for female) than the European specie L. linnearis (20 eggs for female) and now it is more common than the native species $[1,2]$. Another example is the known Indian Meal Moth, Common Clothes Moth, Webbing Clothes Moth, or simply Clothing Moth, Tineola bisselliella (Insecta: Lepidoptera: Tineidae); it is now a pest all over Europe but it was probably imported centuries ago from Asia.

The West Indian drywood termite, Cryptotermes brevis (Walker) (Insecta: Isoptera: Kalotermitidae), is another exotic pest from west India. It was described for the first time in Naples 1997 and in Sicily in 1999 [9], it infests structural lumber and be has caused great damage to many historical buildings and artefacts.

In Europe, Rhynchophorus ferrugineus, Olivier (Coleoptera: Curculionidae), known as the Red Palm Weevil (RPW) was first detected at the beginning of the 1990s in southern Spain and it then spread toSicily, where it has been established since 2005. At present it is the most feared pest in the world for the life, production and commerce of palm trees, and related products are also suffering. However many other problems and indirect consequences have arisen.

\section{The case of the Red Palm Weevil in Sicily}

The Red Palm Weevil (Fig. 1) and its impact - here analysed with an interdisciplinary approach - is already widespread in Europe. After first being reported in Sicily the RPW rapidly attacked Phoenix canariesis, that was a new host for this insect. The RPW causes significant damage to a wide genera of palms, and this makes controlling it as a quarantine pest advisable [10], but after its introduction in Europe the RPW amplified its spectrum of hosts further, including not only Phoenix canariensis, but even the native palm species Chamaerops humilis. In Europe, where infestation exists mainly in urban areas, there is a strong emphasis on the development of IPM (Integrated Pest Management) based on pheromone traps and biological control [11]. Nevertheless, the introduction of the RPW has been caused the loss, in Sicily, of more than 14,000 palms. In the urban areas of Sicily severe damage appears concentrated mainly on $P$. canariensis, followed by $P$. dactyliphera and Washingtonia spp. Before the accidental introduction of the RPW, palm trees in Sicily were never attacked by phytophagous, parasites or pathogens, and for this reason they were considered optimal trees in urban areas.

\subsection{Palm trees and the impact of the RPW on the urban landscape and cultural heritage in Sicily}

In Sicily palms are often used in main squares, promenades, historical and botanical gardens. In fact 35 different species of palms are found in 113 Sicilian historical gardens. The most common palm is $P$. canariensis, present in more than $85 \%$ of the historical gardens, followed by $C$. humilis, Washingtonia filifera, $W$. robusta, P. dactylifera. $C$. humilis is an endemic species while $P$. dactylifera and the other palms, introduced in 11-12th centuries. [12].

Ever since then palm trees have had a strong influence in the urban architecture and landscape, particularly in Palermo, as is evident in the most important squares and streets such as Villa Bonanno (Fig. 2a), the main prospectus of the Cathedral (Fig. 2b), the Teatro Massimo (Fig. 2c), and San Giovanni degli Eremiti (Fig. 2d). Even the many paintings realised by travellers, poets and illustrators of the 18-19th centuries - such as those by Henry Gally Knight - testify to the important role of palms in enhancing the facades of important historical monuments such as the "Cuba" (Fig. 3).

But RPW attacks have brought about a drastic decrease in the number of these plants and caused a radical change in urban spaces, and may yet continue to transform the city. Photos taken in the same place before the introduction of RPW, during its attacks, and nowadays can give a measure of the damage (Fig. 4a and b). Palm trees, moreover, represent an important element of cultural heritage in the Mediterranean area [13]. In Sicily, the Principes plantarum, named by Linnaeus [14], is part of the traditional landscape. Some species, like the $C$. humilis, are endemic, while others were imported from tropical and subtropical regions. One of the reasons for their extensive use is linked to the strong symbolism of these plants. Since ancient times they have been considered a symbol of life and fertility and they are often associated with religion, mythology and tradition [15]. For this reason, over the centuries they have often been represented in decorative arts, mosaics and frescoes, which testifies to their timeless importance. The "palm of victory" originated in the history of the foundation of Rome: the famous Latin poet Ovid tells us that Rea Silvia, before giving birth to Romulus and Remus (the mythological founders of Rome), saw her future sons in a dream, in the form of palm trees [16]. The palm as symbol
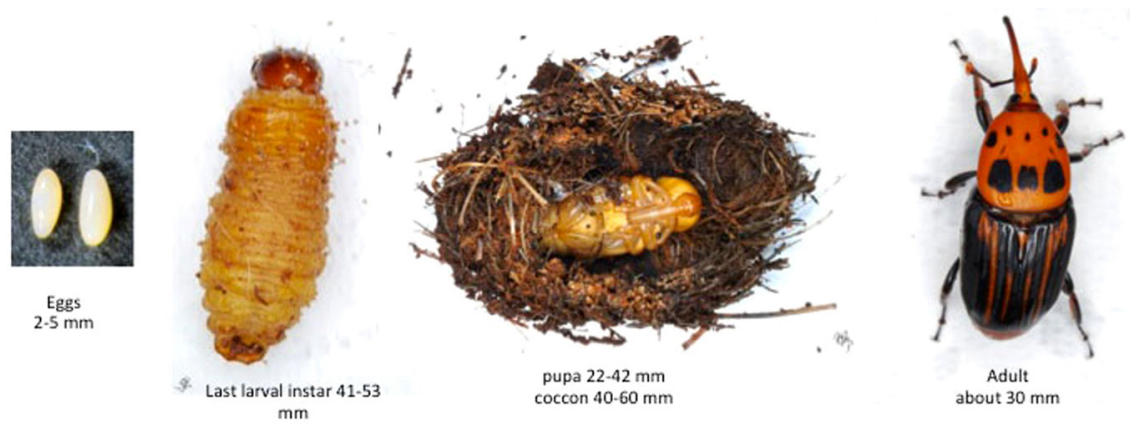

Fig. 1. Rhynchophorous ferrugineus: egg, mature larva, pupa, adult. Photos by F.P. Mancuso. 

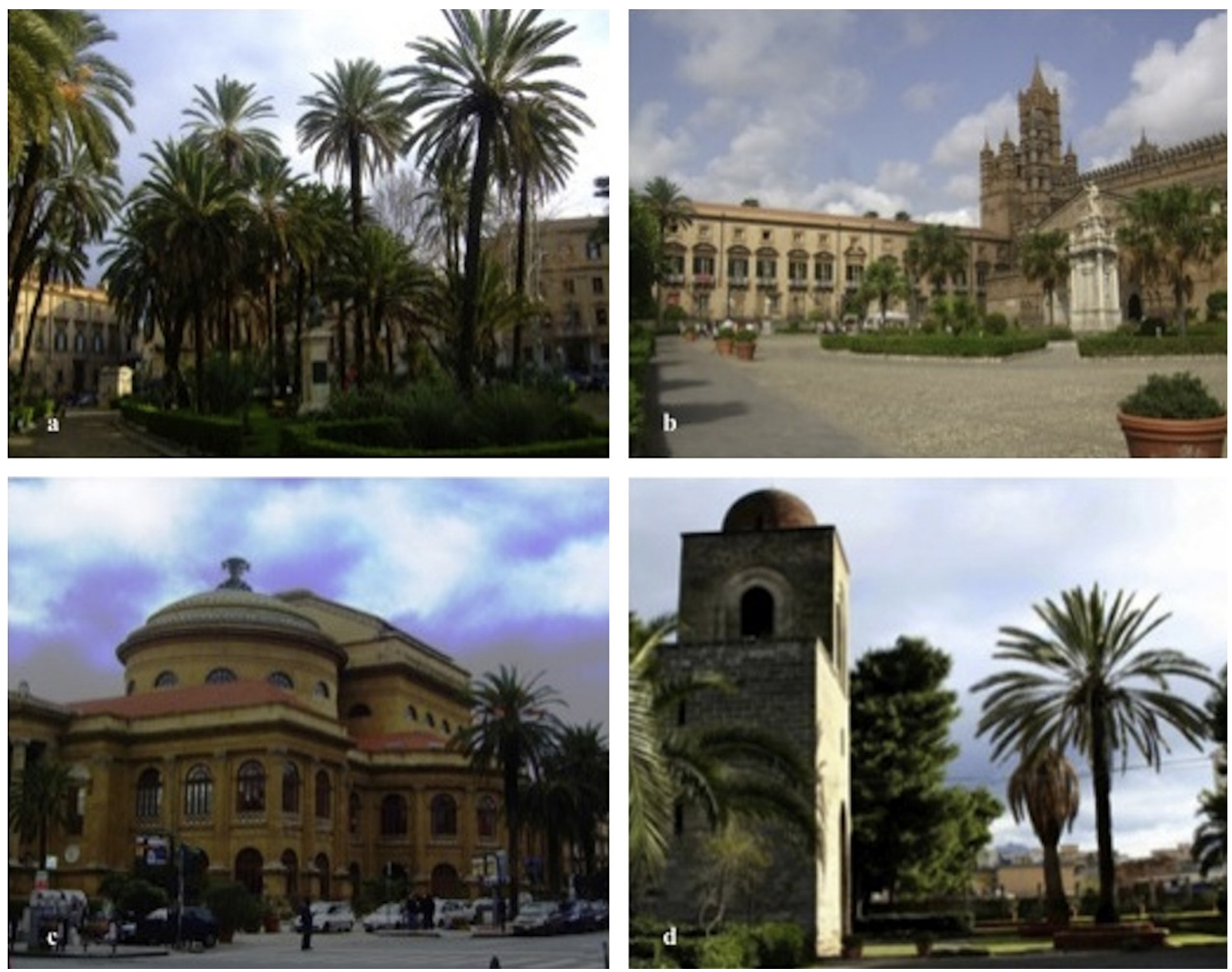

Fig. 2. Four of the most important squares and monuments in Palermo: (a), Villa Bonanno, (b) Cathedral, c) Teatro Massimo, (d) San Giovanni degli Eremiti, notice the palm tree infested by RPW on the right.

of victory can also be found in the mosaics of the roman Villa del Casale in Piazza Amerina (Enna). In fact, in the scenes of the "Piccolo Circo" (southern area of the Villa), four chariots, each standing for a season, are driven by competing Aurigae (Fig. 5a) and a child is holding a palm frond, destined to the winner. Palm fronds are also in the mosaic of the "ten Maidens" (Fig. 5b), depicted as they perform different sports. A woman in a yellow toga is depicted with a crown in her hand and in the adjacent scene, one of the maidens holds the palm of victory.

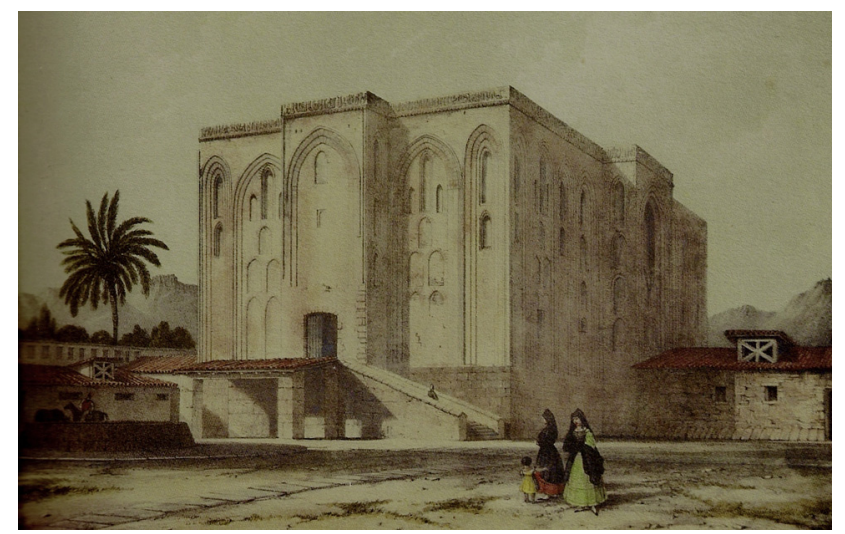

Fig. 3. Gally Knight painting: "The Cuba in Palermo".
It is well known that palms are also represented in most Norman-Byzantine monuments, as in the Royal Palace of Palermo (Palazzo dei Normanni), embellish the prospectus. Moreover palms are represented also in "Jesus' triumphal entry into Jerusalem" (Fig. 6) located in the southern wall of the Palatine Chapel (in the Palazzo dei Normanni); here, the palm tree is an Easter symbol and stands for eternal life and triumph. In the same palace, palms appear in the symmetrical schemes of a mosaic depicting a hunting scene in the hall of King Ruggero, and in other scenes, side by side with other species of trees and animals. Elsewhere they were used as a decorative element in architecture and stone artefacts. In the Christian era the palm represents martyrdom, and as represented in the iconography of Saints, it also takes on the meaning of resurrection [14].

\subsection{The impact of the RPW on natural landscapes, biodiversity and ethno-anthropological handiwork}

C. humilis L. (Arecaceae) is one of the two Palmaceae species native to Europe and represents one of the major species of Mediterranean shrub lands. C. humilis characterizes the coastal areas of Sicily, and in the southern part of the island is able to extend its habitat to medium altitudes ( $600 \mathrm{~m}$ above sea level). In many cases it is a representative species in natural reserves such as the "Zingaro" (Trapani) or "Monte Cofano" (Trapani) or in the protected area Capo Gallo (Palermo). The species is now employed successfully in the design of public and private gardens [17]. 

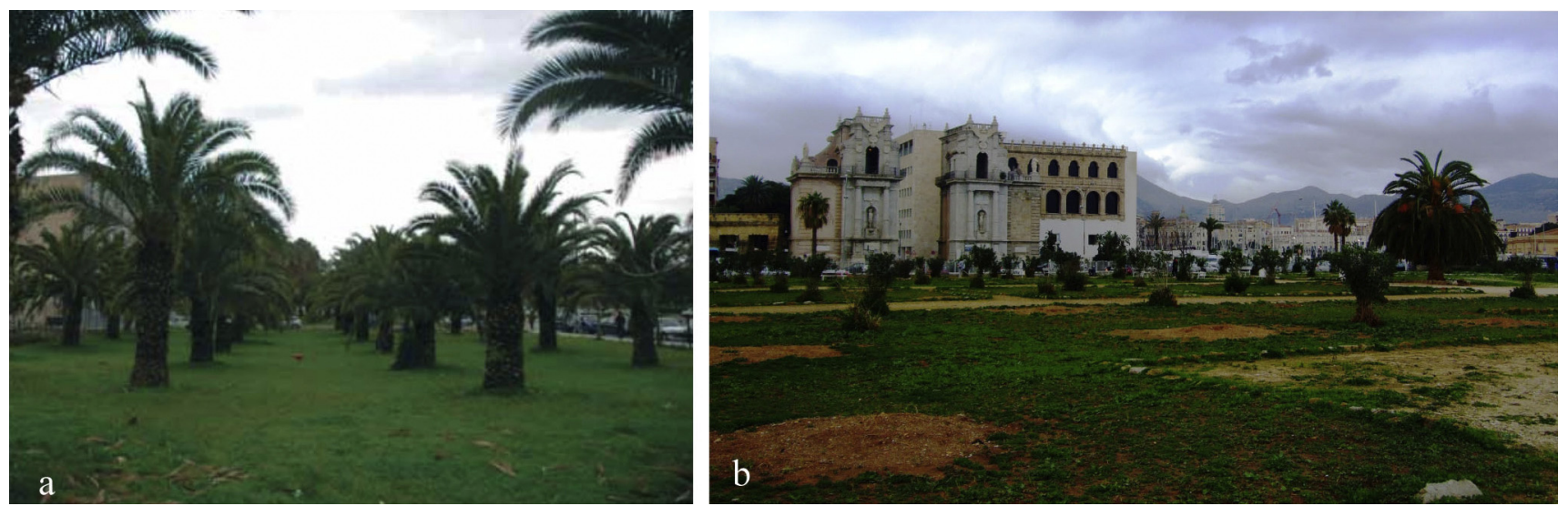

Fig. 4. Palm grove with Phoenix canariensis palm trees, Foro Italico: (a) before and (b) after RPW attack; notice that only one palm is now present.
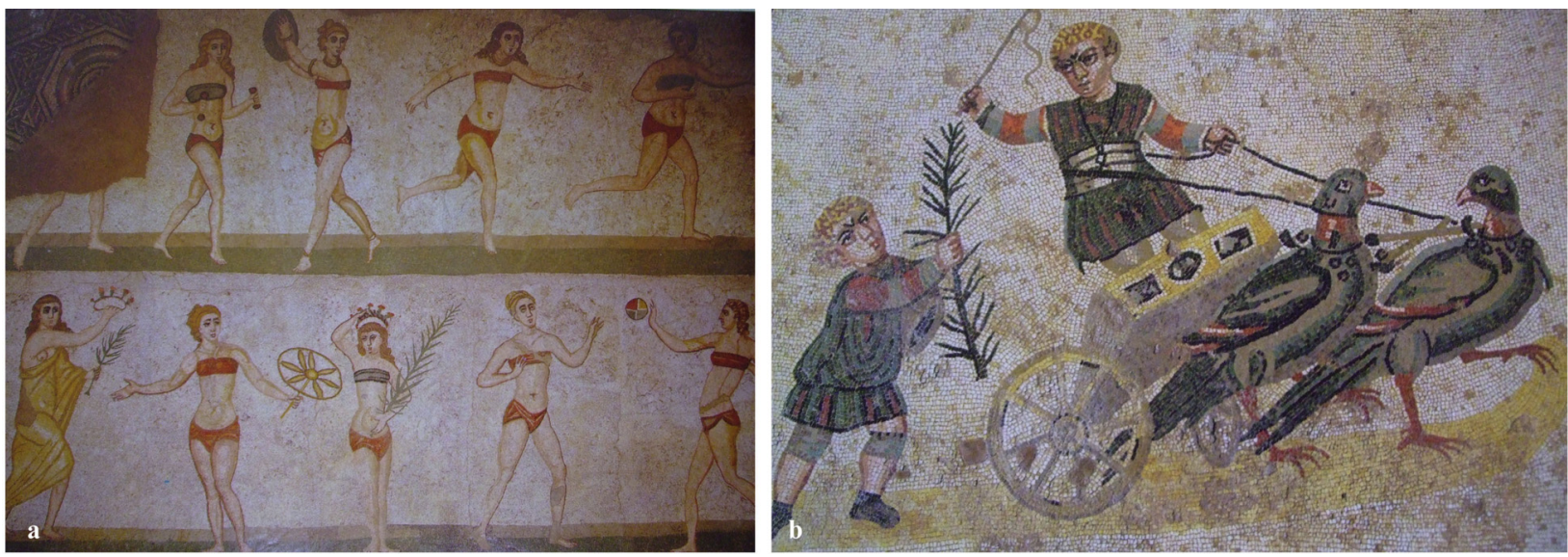

Fig. 5. Roman Villa del Casale in Piazza Amerina (Enna): (a) mosaics of the Piccolo Circo: child giving the palm of victory to the winner Aurigae; (b) mosaic of the ten Maidens: one of the maidens holds the palm of victory.

C. humilis is a dwarf palm that inhabits evergreen forests and xerophytic scrub communities around the Mediterranean region. It is reported that the species is dioecious and presumably windpollinated. Nevertheless, female flowers sometimes secrete nectar, and both male and female inflorescences attract weevils which feed on pollen and young fruits. It is hypothesized that, being anemophilous at present, $C$. humilis bears traits related to an

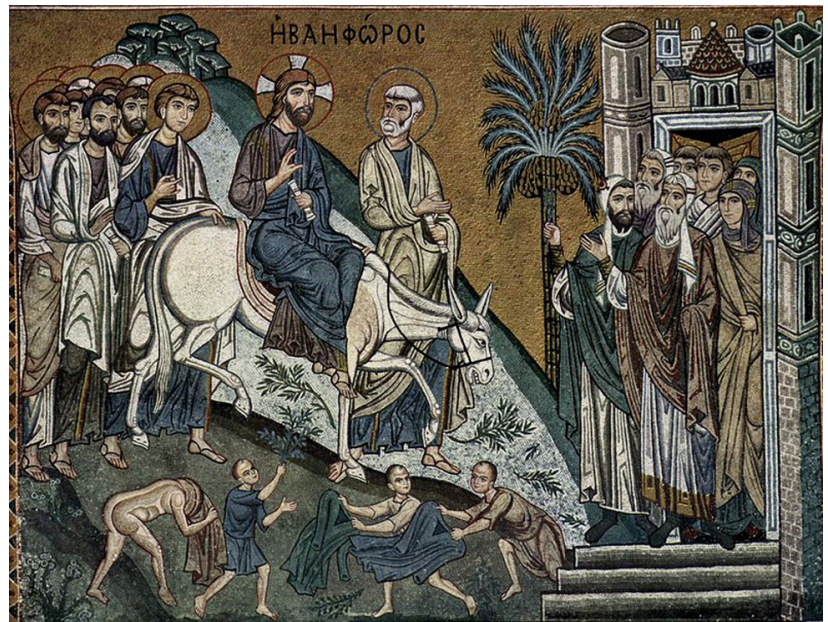

Fig. 6. Royal palace of Palermo, Palatine Chapel; “Jesus' triumphal entry into Jerusalem". earlier insect-pollinated condition. In fact, leaves of $C$. humilis produce volatile compounds that attract their species-specific pollinating weevil, Derelomus chamaeropsis (Insecta, Coleoptera), whereas the flowers are almost scentless. This odour production is limited to anthesis and thus may have a function similar to that of floral scents $[18,19]$. A variety of insects are attracted to the nectar, including ants, beetles and many other insects that probably should not be considered pollinators, but rather unspecialized parasites of flowers and fruits $[18,19]$. Thus C. humilis also has an important role in insect communities [20] and in supporting not only botanical but also animal biodiversity, preserving several endemic species suck as the palm-feeding planthopper Ommatissus binatus [20].

RPW attacks on the native palm C. humilis have been recorded in different areas of Sicily [21], including in protected areas "Zingaro" Trapani. The RPW seems to prefer the oldest $C$. humilis plants but further research is necessary to confirm these observations. In any case, the consequences of these attacks on the Mediterranean ecosystem are not easy to forecast at the moment.

Another aspect of the problem is the traditional importance of palm trees as raw materials in Sicily. Here the endemic species of C. humilis - known in Italian as palma nana (dwarf palm) - is frequently used for the production of the "corina" obtained from the inner leaves.

Traditionally the "corina" was used to produce homemade brooms, bags, hat, brushes, ropes, fans, rush-mats and nowadays, thanks to the skill of certain artisans and designers, it is used to make mobile-phone cases and other design objects (Fig. 7). 

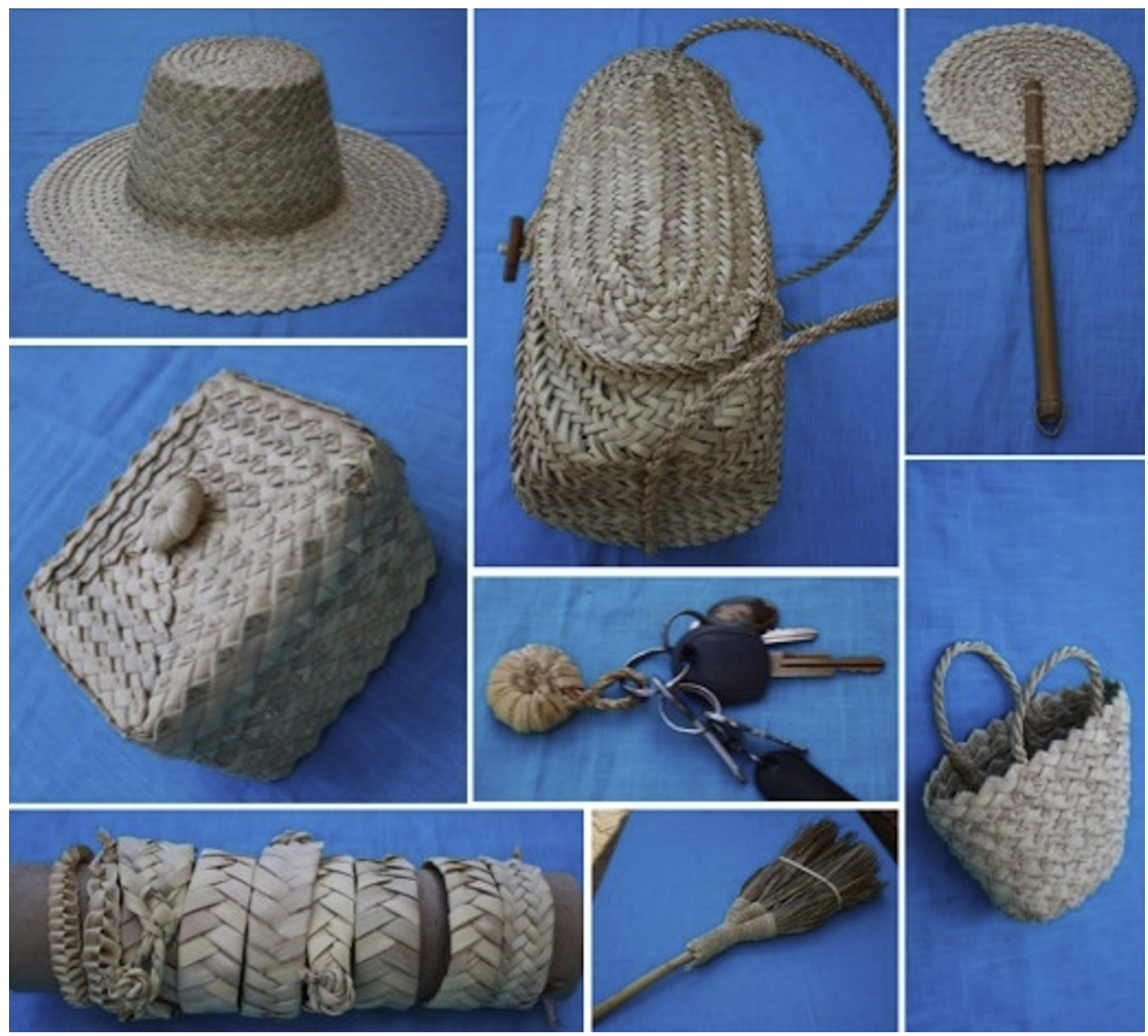

Fig. 7. Different homemade objects made by weaving palm tree fibres.

In the "Zingaro" natural reserve a special course of "intreccio" (the weaving of palm tree fibres) is held each year, to promote and conserve these skills. In the past, stuffing for mattesses and pillows was made of these fibres. Today, tourists purchase interesting souvenirs made of palm fibres.

\section{The importance of specific identification and biomolecular techniques to detect intra- and inter-specific differences in exotic species}

An important aspect that should be considered is the precise identification of species that can be considered potentially exotic. This is particular difficult when pre-adult instars - eggs, larvae, pupa - are introduced. Moreover it has been reported that changes in host preferences could lead or be due to genetic differences and to the formation of a different species or sub-species [22]. It is known that for weevil species, host choice does not only depend on host phenology, but also on other physical and chemical factors, and this could be linked to genetic differentiation. To make a clear assignment of weevil species or race independently of possible morphological plasticity, we decided to use molecular markers. These tools have the additional advantage of being applicable to both immature and adult individuals. We used one mitochondrial and one nuclear marker, because comparison between the two can also enable the detection of hybridization. The mitochondrial marker was the COI gene, which encodes for the first subunit of the cytochrome oxidase, and is one of the most frequently sequenced genes used in insect phylogeny [23] and has already been identified in the RPW [24]. The sequences were compared with GenBank sequences on BLAST [25] and multiple alignments were performed. Mitochondrial and nuclear data show that RP weevils collected in different areas can be recognised at all different instars by molecular analysis [26] and that all weevils coming from different hosts belong to the same specie (data not shown). This leads to the recognition of the potential risk of more extensive attacks on the native palm specie.

\section{The underestimated impact of the RPW "invasion"}

In light of the above considerations, can consideration of the potential damage of exotic species like the RPW be limited only to crops? Over the years, many countries have taken measures to limit the damage the RPW causes. In Sicily and in other areas immediate statutory measures were put in place in an effort to eradicate infestation, however, many now appear to accept its presence as inevitable and, in some cases, little or nothing is done to mitigate its effects. Are continued control measures justified and, if so, should they be modified in any way? The basic factor to be considered is cost-effectiveness: i.e., does the value of the crop needing protection justify the cost of the protective measures? But is this 
consideration sufficient to protect our natural and cultural heritage from attacks by the RPW or other alien species? Or would it leave our urban and natural landscape weakened and thus more susceptible to invasion by other pests?

From a policy perspective, invasive species and natural and cultural heritage issues have largely been kept separate. It is however increasingly apparent that they will require integration to address the common priorities identified below. It should be stated clearly that the management of invasive species can be a key tool for preserving natural and cultural heritage.

One question raised by this observation is whether countries need to wait until they actually intercept infested material or until a pest is well established before they are justified in taking action, or should they be entitled to impose protective measures based on Pest Risk Assessment (PRA). Before answering, perhaps we should consider the impact of our answer. If we elect to follow the first course of action, all of the costs of import inspections, public awareness campaigns, and surveys of trees will be borne entirely by the taxpayer in the country at risk. If the precautionary principle is applied and controls are implemented on the basis of perceived risk, then the cost of compliance would lie with the exporting country, though these costs would probably be partially passed on to the consumer.

Thus should import controls be required for pests that will cause damage primarily to cultural heritage and the landscape rather than direct economic damage in the form of plant mortality?

\section{Recommendations and conclusions}

Perhaps the key lesson stemming from this research is that while we lack full knowledge of the comprehensive impact of invasive species on natural and cultural heritage, the impact perceived thus far has been severe enough to warrant action. Our existing experience and practices indicate the need for a clear path forward in order to minimise the threats of invasive species. With better research, longer-term data and site-level specifics, we will be able to fill in gaps in knowledge and lessen uncertainty regarding future scenarios.

In conclusion, palm trees are present in many different contexts in Sicily: in the landscape, in everyday life, in art, and they have different meanings often related to mythology, religion and tradition. It must therefore be pointed out that since the establishment of the RPW is going to change the ecosystem of the island radically, there is the real possibility that in the future, artefacts, mosaics, paintings and ethnoantropological handiworks will no longer testify to the importance that this plant has had for centuries in the economy, traditions and landscape of this area of the Mediterranean.

This research highlights the importance of an inter/multidisciplinary approach to the forecasting and evaluation of the potential impact of exotic species on natural and cultural heritage.

\section{Acknowledgments}

This study was supported by the Italian Ministry of Education, University and Research (PRIN 2008 47CA28_002). The authors wish to thank the Regional Department of Phytosanitary Structural Intervention for Regional Service Unit No. 53 Region of Sicily and, in particular, the Dr. Castiglia Filippo Regionale Azienda Regionale Foreste Demaniali Servizio 30 Servizio gestione delle aree protette (UOB n. 1) for helping with the sampling and collecting of the RPW larvae and the information regarding natural areas.

\section{References}

[1] A. Gambetta, List of insects intercepted in imported timbers in Italy. Intern. Res. Group on Wood Preserv. IRG/WP Doc. 1217 (1983) 1-3.

[2] E. Ratti, Coleoptera Lyctidae e Bostrichidae intercettati nel porto e negli ambienti urbani di Venezia, Bollettino del Museo Civico di Storia Naturale di Venezia 55 (2004) 121-125.

[3] Biological Emergency, 2012 the Governor's Idaho Weed Summit, Boise, Idaho, http://www.blm.gov/weeds/BOISUMMI.WPD.html (accessed January 2012).

[4] H. Charles, J.S. Dukes, Impacts of invasive species on ecosystem services, Ecological Studies 193 (2007) 217-237.

[5] UNEP FI (United Nations Environment Programme Finance Initiative), Biodiversity and Ecosystem Services, Bust ed., UNEP FI, Genève, Switzerland, 2008 pp. $1-38$.

[6] S.W. Burgiel, A.A. Muir, Invasive species, climate change and ecosystem-based adaptation: addressing multiple drivers of global change, in: Global Invasive Species Programme (GISP), Washington, DC, US, and Nairobi, Kenya, 2010.

[7] M.E. Eiswerth, T.D. Darden, W.S. Johnson, J. Agapoff, T.R. Harris, Input-output modelling, outdoor recreation, and the economic impacts of weeds, Weed Science 53 (2005) 130-137.

[8] U.S. EPA, 2001, Nonindigenous species - an emerging issue for EPA, vol. 1, Region/ORD Nonindigenous Species Workshop Summaries, EPA report, May 2001, Prepared by Environmental Management Support, Inc. and Henry Lee II.

[9] G. Liotta, G. Matranga, Cryptotermes brevis in Sicilia, Informatore Fitopatologico 11 (1999) 27-29.

[10] EPPO (European and Mediterranean Plant Protection Organization), Data sheets on quarantine pests - Rhynchophorus ferrugineus, EPPO Bulletin 38 (2008) 55-59.

[11] B. Manachini, V. Arizza, D. Parinello, N. Parrinello, Hemocytes of Rhynchophorus ferrugineus (Olivier) (Coleoptera: Curculionidae) and their response to Saccharomyces cerevisiae and Bacillus thuringiensis, Journal of Invertebrate Pathology 106 (2011) 360-365.

[12] G. Barbera, D. Romano, Le palme nel paesaggio Siciliano, in: In Regione Siciliana: La Ricerca Scientifica sul Punteruolo Rosso e gli altri Fitofagi delle Palme in Sicilia, Centro Stampa Rubino, Marsala, 2009, pp. 29-38.

[13] S. Cusa, La Palma Nella Poesia, Nella Scienza e Nella Storia Siciliana, Ristampa anastatica di Bruno Leopardi Editore, Palermo, 1998

[14] G. De Micheli, E. De Santis, Palma Palmae, Edizioni Pendagron, Bologna, 2001.

[15] D. Romano, Le Palme Nella Storia e Nel Paesaggio Siciliano, Dipartimento di OrtoFloroArboricoltura e Tecnologie Agroalimentari, Università Degli Studi di Catania, Italy, 2005 http://www.accademiadeglizelanti.it/2005/lepalme.pdf

[16] J. BROSSE, Mitologia Degli Alberi, Dal Giardino Dell'eden al Legno Della Croce, BUR Rizzoli, Milano, 1998.

[17] M. Airò, G. Giardina, G. Farruggia, G.V. Zizzo, A. Giovino, Preliminary study on Chamaerops humilis L. propagation, Acta Horticulturae 898 (2011) 39-44.

[18] J. Herrera, On the reproductive biology of the Dwarf Palm, Chamaerops humilis in Southern Spain, Principles 33 (1) (1989) 27-32.

[19] J.C. Caissard, A. Meekijjironenroj, S. Baudino, M.-C. Anstett, Localization of production and emission of pollinator attractant on whole leaves of Chamaerops humilis (Arecaceae), American Journal of Botany 91 (8) (2004) 1190-1199.

[20] F.W. Howard, D. Moore, R. Giblin-Davis, R. Abad, Insects on Palms, CABI Publications, Wallingford, UK, 2001, 400 pp. http://www.agrinnovazione.regione. sicilia.it/aggiornamenti/eventi/2009/aprile/file/punteruolo\%20rosso.pdf

[21] S. Longo, P.J. Anderson, T.R. Smith, J.D. Stanley, R.N. Inserra, New palm hosts for the red palm weevil, Rhynchophorus ferrugineus, in Sicily, Palms 55 (1) (2011) $15-20$.

[22] M. Drès, J. Mallet, Host races in plant-feeding insects and their importance in sympatric speciation, Philosphical Transactions of the Royal Society London B 357 (2002) 471-492.

[23] M.S. Caterino, S. Cho, F.A. Sperling, The current state of insect molecular systematics: a thriving Tower of Babel, Annual Review of Entomology 45 (2000) $1-54$.

[24] F. Palla, B. Manachini, Cytochrome oxidase subunit I-like (COI) gene, partial sequence; mitochondrial Rhynchophorus ferrugineus (Red Palm Weevil) 863 bp DNA linear INV 2008, 2008

[25] NCBI EU780007. http://www.ncbi.nlm.nih.gov/sites/entre

[26] B. Manachini, F. Palla, Analisi molecolare per lo studio della variabilità genetica nel punteruolo rosso, la ricerca scientifica sul Punteruolo rosso e gli altri fitofagi delle palme in Sicilia 1 (2009) 129-132. 